\title{
Epidemiological Study of Camel Ectoparasites in Different Districts of Afar Region, Ethiopia
}

\author{
Endris Feki ${ }^{1, \text { * }}$, Beksisa Urge², Weldegebrial G. Aregawi², Tamirat Siyoum ${ }^{2}$, Ali Shiferaw ${ }^{3}$ \\ ${ }^{1}$ Afar Pastoral and Agro-pastoral Research Institute, Semera, Ethiopia \\ ${ }^{2}$ Ethiopian Institute of Agricultural Research (EIAR), Addis Ababa, Ethiopia \\ ${ }^{3}$ Semera Animal Health and Diagnostic Laboratory, Semera, Ethiopia
}

Email address:

endrisf@yahoo.com (E. Feki)

${ }^{*}$ Corresponding author

\section{To cite this article:}

Endris Feki, Beksisa Urge, Weldegebrial G. Aregawi, Tamirat Siyoum, Ali Shiferaw. Epidemiological Study of Camel Ectoparasites in Different Districts of Afar Region, Ethiopia. European Journal of Preventive Medicine. Vol. 9, No. 5, 2021, pp. 114-118. doi: 10.11648 j.ejpm.20210905.11

Received: August 18, 2021; Accepted: September 1, 2021; Published: September 10, 2021

\begin{abstract}
A cross-sectional study was conducted from April, 2017 to October 2018 to investigate the occurrence of major camel ectoparasites and associated risk factors in selected districts of Afar Regional State, Ethiopia. Out of the total camels $(\mathrm{N}=813)$ examined for ectoparasite infestation, about 629 of camels were infested with one or more species of parasites and the overall prevalence was $77.4 \%$. About $17.44 \%, 10.57 \%, 1.97 \%$, and $0.24 \%$ were accounted for single and mixed infestation with two, three and four parasites respectively. The study indicated that there were statistically significant variation $(P<0.05)$ in the prevalence of ectoparasites among sex, age group and body condition; However, there was no significant variation $(\mathrm{P}>0.05)$ in infestation rate in relation to areas. In this study four of genera ticks and one genera of mite were identified. The identified genera were Hyalomma (28.30\%), Amblyomma (24.48\%), Rhipicephalus (17.17\%) and Boophilus (0.32\%). The infestation of a single mite showed that; Sarcoptes scabiei var cameli (8.90\%). Infestations in seven districts in the region ranged (70.06\%) of Yallo $82.6 \%$ in Elidar district to but higher prevalence was found (80.5\%) at Megale and (82.6\%) Elidar district. In conclusion, the prevalence of ectoparasites in the present study was high in camel population in the study areas of the Afar region; therefore it is important to reduce parasitic infestation and its load through applying ectoparasitic drugs and externally applied chemicals.
\end{abstract}

Keywords: Camel Dromedaries, Ectoparasite, Prevalence, Risk Factor, Tick

\section{Introduction}

Camels (Camelus dromedarius) are animals of significant socio-economic importance that are best adapted to harsh environments and fluctuating nutritional conditions of arid and extreme arid zones. Camels are a subset of huge livestock resources in Ethiopia with the population estimated to be over one million. Camel production is the main source of livelihood The camels are valued as riding, baggage, drought animal as well as best food provider in the arid areas. They are important milk producers in arid lands and camel milk is an essential food for livelihood of people and it may be the only milk available in places where other milking animals cannot be maintained. Besides this, camel is an important animal component of the fragile desert eco-system, with its unique bio-physiological characteristics and has become an icon of adaptation to challenging ways of living in arid and semi-arid regions [3]. The productivity of camel is affected by several factors among which parasites are the major ones. Disease caused by ecto-parasites and endoparasites result in major economic losses and hinder improvements in production and productivity efficiency of camel Borji et al [4]. Gastrointestinal parasites are also the major camel health problems that reduce production performance of camel. Ectoparasites such as mange mites, ticks and insects are responsible for disease transmission and block efficiency of productivity and performance of working camles [10]. Losses are due to mortality, lowering of reproductive and growth rate, weight losses, reduced hide 
value, milk production and increased cost of production as a result of extra veterinary drugs costs. Other important camel disease such as sarcoptic manges which is caused by a burrowing mite Sarcoptes scabiei var cameli affects young, stressed adult and develop the chronic generalized form of mange [6].

The ecto-parasites harm the camel due to their parasitic nature and serve as a vector for transmission of wide variety of pathogens and diseases. Despite these facts, information is limited on distribution of ecto-parasites in the current study areas. Hence, this study would generate basic information on camel ecto-parasites and mitigation methods in different areas afar region. Therefore, the objectives of the study were:

1) To determine the species of external parasites of camels and putative risk factors.

2) To determine the infestation rate of ecto-parasites and recommend possible control and prevention options.

\section{Material and Methods}

\subsection{Study Area}

The study was conducted from April to October 2018. The Afar National Regional State is one of the nine federal states of Ethiopia located in the northeastern part of the country $588 \mathrm{kms}$ far from the capital. The total geographical area of the region is about $270,000 \mathrm{~km}^{2}$. It is geographically located between $39^{\circ} 34^{\prime}$ and $42^{\circ} 28^{\prime}$ 'East Longitude and $8^{\circ} 49^{\prime}$ and $14^{\circ} 30^{\prime}$ North Latitude The climate in most of the region is hot with maximum temperature of $45^{\circ} \mathrm{C}$ in August and minimum temperature of $20^{\circ} \mathrm{C}$ in January. The altitude ranges from $116 \mathrm{~m}$ below sea level to $1500 \mathrm{~m}$ above sea level. The region has an area of Low Land, with an irregular drainage system and depression, which, is $114 \mathrm{~m}$ below sea level as well as some of the exposed rocks. $35.47 \%$ of the region has an elevation less than $400 \mathrm{~m}$ above sea level whereas $51.44 \%$ has an elevation between 400 to 900 and $13.09 \%$ has an elevation above $900 \mathrm{~m}$ above sea level. The region has a number of perennial rivers that include Awash, Mille, Kesem Kebena, Awura, Gulina, Dewe, Borkena, Telalak, and numerous seasonal rivers that flows to different basins. In the region there are also a number of lakes, such as Lake Asahle, Lake Dalol, Lake Afdera, Lake Abe, and Lake Gemeri are some examples of the lakes in the region. The study was conducted in seven districts of afar national regional state namely Chifra, Erebti, Burimodayito, Gewane, Dalifage, Yallo and Elidar which are potential areas for camel.
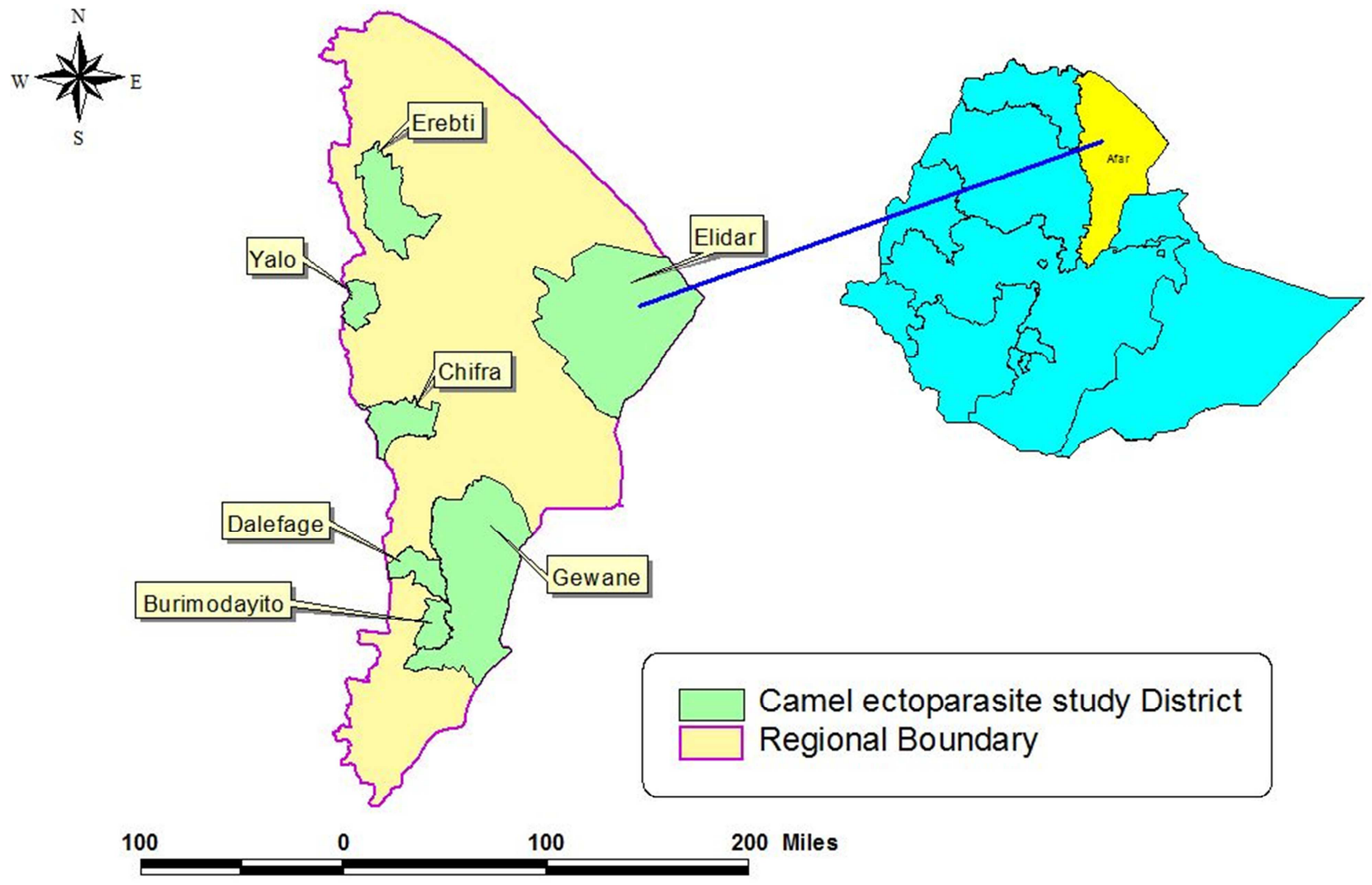

Figure 1. Map of the Study Districts.

\subsection{Study Animals}

The study was conducted on traditionally managed camel herd randomly selected kebels (Pas) of the selected seven districts of the five zones. For the prevalence study, age groups and sexes would be randomly selected from different herds. Due to the absence of written records, the age of animal was determined by dentition. Study animal related 
information on each tested camel such as sex, age and body condition score were collected at the time of the study. In this study, indigenous breeds of camel (one hump camel) are categorized under camellus dromedarous breed group. Animals that had not treated for at least two month prior to sampling for ectoparasites.

\subsection{Study Design}

A cross sectional study was conducted for determination of the occurrence and prevalence of infestation in selected districts for camel rearing. From each district two sites or kebeles were selected which were 14 sites from the entire five zones. The study districts were selected based on the inclusion criteria such as potential camel population, accessibility, and willingness of the pastoralists to participate in the study.

\subsection{Sample Size Determination}

Sample size was determined according to Thrusfield [12]. Using an average expected prevalence rate of $50 \%$ (as there was no previous report in the districts), 95\% confidence intervals (CI) at 5\% desired accuracy. Accordingly, a total of 384 animals were calculated to be included in the study was inflated to 813 in order to increase the representativeness of the samples to the wider population. Sampling animals were proportionally distributed to selected districted and PAs based on their camel population.

\subsection{Laboratory Sampling}

Tick sample collection was done and gently removed by horizontal pull to the body surface by rotating the tick not to damage the tick's mouth parts and then all collected ticks were preserved in properly labeled plastic container containing $70 \%$ ethanol. Skin scrapings from suspected cases of mange were taken to laboratory, $10 \% \mathrm{KOH}$ were added to the specimen so that mites released from scabs and crusts before examination following procedures indicated by Souls by [11]. Identification of the mange mite species was based on the morphological characteristics described by Urquhart et al. [13]. The collected ticks were identified to their species level by using tick identification keys according the guidelines indicated by Walker et al. [14].

\subsection{Ethical Regulation}

Handling, sampling and all of animal related contacts were in according to ethical regulation stand art of pastoral agropastoral Research Institute of Ethiopia.

\subsection{Statistical Analysis}

The collected data were entered and coded to computer using excel spreadsheets and analysis was carried out using STAT, version 11. The prevalence $(p)$ calculated as $p=d / n$, where $d$ is the number of camels diagnosed as having a given parasite egg/oocyst at that point in time and $n=$ number of camels at risk at that point in time. Descriptive statistics was used to show the frequencies and chi square analysis was used to indicate the significance. The level of significance was set at $\mathrm{P}<0.05$.

\section{Result}

\subsection{Prevalence of Camel Ectoparasites}

A total of 813 camels were examined to determine the prevalence of ecto-parasite infestation in 7 districts of Afar region. Out of these, $629(77.4 \%)$ were infested one or mixed by ecto-parasites. Ticks were identified as the predominant ectoparasites followed by mite (Sarcoptes scabiei var cameli) in infested camels. The overall prevalence of ectoparasite infestation was $573(91.10 \%)$ and $56(8.90 \%)$ in tick and mites respectively. Single (61.26\%) and mixed infestation with two and three parasites were $14.15 \%$ and $1.97 \%$ respectively (Table 2 ).

Table 1. Prevalence and occurrence of ectoparasites in camels $(n=813)$.

\begin{tabular}{llll}
\hline \multirow{4}{*}{ Type of } & $\begin{array}{l}\text { Name of } \\
\text { ectoparasites }\end{array}$ & $\begin{array}{l}\text { No infested } \\
(\mathbf{\%})\end{array}$ & Prevalence (\%) \\
\cline { 2 - 4 } ectoparasites & Tick & 573 & 91.10 \\
& Mange & 56 & 8.90 \\
& Over all infestation & 629 & 100 \\
\hline
\end{tabular}

Table 2. Single and mixed ecto-parasite infestation.

\begin{tabular}{lll}
\hline Infestation type & Positive samples & Percentage (\%) \\
\hline Single parasite & 498 & 61.26 \\
Two parasites & 115 & 14.15 \\
Three parasites & 16 & 1.97 \\
No. parasites & 184 & 22.63 \\
Total & 629 & 77.40 \\
\hline
\end{tabular}

Out of the examined animals, about 629 (77.4\%) of camels were infested. Ectoparasite Infestation in seven districts in the region ranged $(70.06 \%)$ of Yallo to $82.6 \%$ in Elidar district but higher prevalence was found $(80.5 \%)$ in Megale district and (82.6\%) Elidar district (Table 3).

Table 3. Ecto parasite infestations of camels in different districts.

\begin{tabular}{lllll}
\hline Factor & Category & $\begin{array}{l}\text { No. } \\
\text { examined }\end{array}$ & $\begin{array}{l}\text { No. positive } \\
\text { samples }\end{array}$ & $\begin{array}{l}\text { Prevalence } \\
(\%)\end{array}$ \\
\hline \multirow{6}{*}{ Districts } & Chifra & 115 & 92 & 80.0 \\
& Gewane & 119 & 85 & 71.4 \\
& Bure Mudaytu & 114 & 90 & 78.9 \\
& Elidar & 115 & 95 & 82.6 \\
& Yalo & 119 & 84 & 70.6 \\
& Dalifage & 113 & 88 & 77.9 \\
& Megale & 118 & 95 & 80.5 \\
& Total & 813 & 629 & 77.4 \\
\hline
\end{tabular}

Pearson $\mathrm{chi}^{2}=8.6238 \mathrm{Pr}=0.196$ (No significant variation).

\subsection{Occurrence of Ectoparasites by Genus Level}

The identified genera were Hyalomma (28.30\%), Amblyomma (24.48\%), Rhipicephalus (17.17\%) and Boophilus $(0.32 \%)$. Sarcoptes scabiei var cameli was identified as the only mite species in skin scarping samples $(8.90 \%)$. 
Table 4. Prevalence of ectoparasites by Genus level.

\begin{tabular}{llll}
\hline Types & Genus & No. positive sample & Prevalence (\%) \\
\hline & Hyalomma & 178 & 28.30 \\
& Amblyomma & 154 & 24.48 \\
& Rhipicephalus & 108 & 17.17 \\
& Boophilus & 2 & 0.32 \\
& Rhipicephalus and Amblyomma & 37 & 5.88 \\
& Rhipicephalus and Bophilus & 26 & 4.13 \\
Ticks & Rhipicephalus and Hyalomma & 21 & 3.34 \\
& Hyalomma and Amblyomma & 21 & 3.34 \\
& Rhipicephalus, Bophilus and Amblyomma & 9 & 1.43 \\
& Amblyomma and Bophilus & 6 & 0.95 \\
& Hyalomma and Bophilus & 4 & 0.64 \\
& Rhipicephalus, Hyalomma and Bophilus & 4 & 0.64 \\
& Rhipicephalus, Hyalomma and Amblyomma & 3 & 0.48 \\
& Sarcoptes & 56 & 8.90 \\
\hline
\end{tabular}

\subsection{Prevalence of Ectoparasites in Camel in Relation to Risk Factors}

The prevalence of ectoparasite in female and male was $89.4 \%$ and $56.9 \%$ respectively. The prevalence of ectoparasites was significantly influenced by sex, Age, and body condition score of camels $(\mathrm{P}<5 \%)$ (Table 5).

Table 5. Prevalence of ectoparasites in camel by different host related factors.

\begin{tabular}{|c|c|c|c|c|c|c|}
\hline \multirow{2}{*}{ Variable } & \multirow{2}{*}{ category } & \multirow{2}{*}{ No. examined } & \multicolumn{2}{|l|}{ Prevalence } & \multirow{2}{*}{ Chi-square } & \multirow{2}{*}{ P-value } \\
\hline & & & No. Positive & Percentage (\%) & & \\
\hline \multirow{2}{*}{ Sex } & Female & 511 & 457 & 89.4 & \multirow{2}{*}{114.3} & \multirow{2}{*}{0.000} \\
\hline & Male & 302 & 172 & 56.9 & & \\
\hline \multirow{2}{*}{ Age } & Young & 244 & 122 & 50 & \multirow{2}{*}{149.1} & \multirow{2}{*}{0.000} \\
\hline & Adult & 569 & 507 & 89.1 & & \\
\hline \multirow{2}{*}{ BCS } & Good & 178 & 48 & 27.0 & \multirow{2}{*}{330.6} & \multirow{2}{*}{0.000} \\
\hline & Poor & 635 & 581 & 91.5 & & \\
\hline
\end{tabular}

\section{Discussion}

Camels provide milk and meat for the pastoralists in the arid lowlands of Ethiopia [15]. In the present study, the overall prevalence of ectoparasites infestation was 629 $(77.40 \%)$ in camels. Ectoparasite Infestation in the current districts was $(70.06 \%)$ in Yallo and $82.6 \%$ in Elidar district. The current result was in line with the study of Dinka et. al [5]. In Dire Dawa but different from the works of Rahmeto et. al. [9] in Jijiga zone who reported high tick prevalence in camel living areas. This variation could be due to climatic conditions. The finding was also lower than the prevalence reported by Kiros et al. [7]. Who reported $96.61 \%$ tick infestation in Southern Tigray, Ethiopia. The variation could be due to climate conditions, poor husbandry practices, and inadequate veterinary services in study areas. Out of 813 camels examined, about $91.10 \%$ and $8.10 \%$ of camels were infested with ticks and mite respectively. The identified genera were Hyalomma (28.30\%), Amblyomma (24.48\%), Rhipicephalus (17.17\%) and Boophilus (0.32\%). This result could be related with the finding of $[7,8]$.

Hyalomma dromedarii with prevalence of (17.17\%) was the dominant ticks identified in the current study areas. Similar finding was reported by $[5,17]$. The study also indicated Sarcoptes scabiei var cameli $(8.9 \%)$ was the only mite species identified from skin scarping samples. The result was lower than the study of [16] who reported $27.8 \%$ prevalence in Somali Region but higher than the results reported by [1] with the prevalence of $3.5 \%$ in North Ethiopia. The might be due to management practices. In this study, the higher prevalence of ectoparasite infestation was recorded in female $(89.4 \%)$ than male $(56.9 \%)$ categories and there was significant variation $(\mathrm{P}<0.05)$. This observation was in line with [2]. The variation could be explained as females were properly managed than males. Adult camels were mostly infested $(89.1 \%)$ than young $(50 \%)$ age groups and the variation was significant $(\mathrm{P}<$ 0.05). Higher exposure risk of adult animals might be explained as contact at grazing and watering points with infested animals facilitate the parasite transmission and management systems.

\section{Conclusion}

The study showed that the overall camel ectoparasites prevalence was $77.40 \%$. The ectoparasites infestation was $573(91.10 \%)$ and $56(8.90 \%)$ in tick and mites respectively. Single $(61.26 \%)$ and mixed infestation with two and three parasites were $14.15 \%$ and $1.97 \%$ respectively. The study indicated that there were statistically significant variation $(P$ $<0.05)$ in the prevalence of ectoparasites among sex, age group and body condition. In conclusion, the prevalence of ectoparasites in the present study was high in camel population in the study areas of the Afar Region. 


\section{Recommendations}

It is important to reduce parasitic infestation and its load through applying ectoparasitic drugs and it is valuable to implement effective extension services and training programs aiming at awareness creation about the importance and control of ecto-parasites for camel owners is very important in the study areas.

\section{Declarations}

\section{Authors' Contribution}

All authors contributed equally to this research work. All authors read and approved the final manuscript.

\section{Availability of Data and Materials}

Data will be made available up on request of the primary author.

\section{Competing Interest}

The data can be available to the journal upon request.

\section{Conflict of Interest}

The authors declare that they have no competing interests.

\section{Acknowledgements}

The authors thank and would like to acknowledge Semera Animal Health and Diagnostic Laboratory for their support during sample collection and processing.

\section{References}

[1] Awol, N., K. Semere, T. Yisehak, A. Mohammed and H. Birhanu, 2014. Study on mange mite of camel in Raya-Azebo district, northern, Ethiopia. https://pubmed.ncbi.nlm.nih.gov/25568694/

[2] Ayele T.; Mohammed M. (2013): A Study on Camels Ticks in and Around Dire Dawa, Eastern Ethiopia. Acta Paras. Glob, 4 (2): 64-70. https://www.idosi.org/apg/4(2)13/6.pdf

[3] Bikaner Website (2008): Online Article on Camel, National Research Center on Camel, Jorbeer, Bikaner India. https://nrccamel.icar.gov.in/

[4] Borji, H., G. Razmi, A. R. Movassaghi, A. G. Naghibi and M. Maleki. (2010): A study on gastrointestinal helminths of camels in Mashhad abattoir Iran. Iranian journal of Veterinary Research, 11: 174-179. file://C:/Users/Toshiba/Downloads/Music/Documents/IJVR_ Volume\%2011_Issue\%202_Pages\%20174-179.pdf

[5] Dinka, A., B. Eyerusalem and H. T. Yacob, 2010. A study on major ectoparasites of camel in and around Dire-Dawa, Eastern Ethiopia. Revue Méd. Vét., 161 (11): 498-501. https://www.revmedvet.com/2010/RMV161_498_501.pdf

[6] Dioli, M. and R. Stimmelmayr, 1992. Important camel diseases, health care and management. Schonwald Druck, Berlin, pp: 155-224. Link Google Scholar https://agris.fao.org/agris
search/search.do?recordID=DE93R0024

[7] Kiros, S., N. Awol, Y. Tsegaye and B. Hadush, 2014. Hard Ticks of Camel in Southern Zone of Tigray, Northern Ethiopia. J. Parasitol. Vector Biol., 6 (10): 151-155. https://www.researchgate.net/publication/272367828_Hard_Tic ks_of_Camel_in_Southern_Zone_of_Tigray_Northern_Ethiopia

[8] Megersa, B., D. Abreham, B. Jemere, A. Bedane and S. Desie, 2012. Ticks and mange mites infesting camels of Boran pastoral areas and the associated risk factors, southern Ethiopia. Journal of Veterinary Medicine and Animal Health, 4 (5): 71-77. https://academicjournals.org/journal/JVMAH/article-full-textpdf/E6353C34652

[9] Rahmeto, A., F. Thedrous, A. Mesele and B. Jemere, 2010. Survey of ticks (Acari: Ixodidae) infesting cattle in two districts of Somali Regional State, Ethiopia. Vet. World., 3 (12): 539-543. file:///C:/Users/Toshiba/AppData/Local/Temp/21291912903.pdf

[10] Shawan, W. (2011): Common intestinal parasite of camels. Vet and pet health.

[11] SOULSBY, E. J. L. (1982): Helminths, Arthropods and Protozoa of Domestic Animals, $7^{\text {th }}$ Edn. Bailliere Tindall, London. UK, PP. 231-250. Link, Google Scholar https://kupdf.net/download/paniker39s-textbook-of-medicalparasitology-7e-2013-pdfunitedvrgpdf_596ebdd8dc0d60f72ca88e84_pdf

[12] Thrusfield, M., 2005. Veterinary Epidemiology, 3 edn. Blackwell Science Ltd, UK. pp: 233-250. Google Scholar https://dvmbooks.weebly.com/uploads/2/2/3/6/22365786/1._v eterinary_epidemiology_thrush_filled.pdf

[13] Urquhart G. M, Armour J, Duncan J. L, Dunn A. M, Jennings F. W (1996): Veterinary Parasitology Second Edn. Blackwell Science Ltd., UK. pp. 307. Link Google Scholar https://www.abebooks.com/Veterinary-Parasitology-UrquhartArmour-Duncan-Dunn/1429962396/bd\#\&gid=1\&pid=1

[14] Walker, A. R., A. Bouattour, J. J. Camicas, P. A. Estrada, I. G. Horak, A. A. Latif, R. G. Pegram and P. M. Preston, 2003. Ticks of domestic animals in Africa: A Guide to Identification of Tick species. Bioscience Report, pp: 1-122. Link Google Scholar file://C:/Users/Toshiba/Downloads/Music/Documents/tickguideafrica.pdf

[15] Wosene, A. (1991): Traditional husbandry practices and major health problems of camels in the Ogaden, Ethiopia. Nomadic People, 29: 21-30. Link Google Scholar https://www.jstor.org/stable/43123335?seq=1

[16] ZELALEM T. 1994: Survey on mange mites and ticks of camels and small ruminants in Dire Dawa Region, Eastern Ethiopia. D. V. M. thesis F. V. M. A. A. U. Ethiopia https://www.google.com/search?q=Zelalem,+T.+(1994):+Survey + on + mange + mites + and + ticks + of + camels + and + small + ruminants + in + Dire+DawaRegion, + Eastern+Ethiopia. + D.V.M+Thesis, + DV M+AAU.+Ethiopia.\&sxsrf=ALeKk00G5QLCafZtNa4YMm35-M0eYcxFQ:1618484642980\&ei=oh14YPOyO5HKgQbrgYWIB A\&start $=20 \&$ sa $=$ N\&ved $=2$ ahUKEwjziCRjYDwAhURZcAKHetAAUE4ChDy0wN6BAgBEDY\&biw= 1366\&bih $=635$

[17] Zeleke, M. and T. Beleke, 2004. Species of ticks on camels and their seasonal population dynamics in eastern Ethiopia. Trop. Anim. Health Prod., 36: 225-231. file:///C:/Users/Toshiba/AppData/Local/Temp/Species_of_Tic ks on Camels and Their_Seasonal Popu.pdf 